Journal of Primary Education
$9(5)(2020): 554-561$
UNNES
https://journal.unnes.ac.id/sju/index.php/jpe

\title{
Effectiveness of Environmental Based Thematic Learning Tools (EBTLT) in Improving the Science Literacy Skills
}

\author{
Rubita Harisna $^{1 凶}$, Joko Sutarto $^{2}$ \\ DOI: https://doi.org/ 10.15294/jpe.v9i5.43583 \\ 1. SDN 6 Tubanan Kabupaten Jepara, Indonesia \\ 2. Pascasarjana, Universitas Negeri Semarang, Indonesia
}

\begin{abstract}
Article Info
Abstract

History Articles

Environment-based learning is needed to increase student's activity through Received:

24 September 2020

Accepted:

25 October 2020

Published:

31 December 2020 environmental empowerment, which can solve the problems in society as well as to improve students' scientific literacy. The objective of this research was to analyze the effectiveness of environment-based thematic learning on fourth grade by contextual approach in improving students' scientific literacy skills. This research is a quasi-experimental research by implemented EnvironmentalBased Thematic Learning Tools (EBTLT). The subject of this research is

Keywords: Environmental Based Thematic Learning Tools (EBTLT),

Science Literacy Skills, Student's activities, Student's characters determined by purposive cluster. They were 25 students as control class, 33 students as the experiment class 1 , and 27 students as the experiment class 2 . The data analysis was used completeness test, N-Gain analysis, and independent sample t-test. The results showed that the first experimental class and second experimental class students achieve classical completeness $>75 \%$, the value has increased after implemented EBTLT in high category. The average score of science literacy skills and student activity in both experimental class was higher than that of the control class. It can be concluded that students who received EBTLT more effective in improving science literacy skills than students who received basic learning and the activities can create character values for learners.
\end{abstract}

\footnotetext{
Correspondence address:

JL. Ki Agung Alim Tubanan, RT. 2, RW. 2, Dusun Timbul, Desa

Tubanan, Kembang, Tuban, Tubanan, Jepara, Kabupaten Jepara,

Jawa Tengah

E-mail: bittabie92@gmail.com
} 


\section{INTRODUCTION}

The presence of the 2013 curriculum is expected to be able to improve Indonesian education to face the Golden Generation in 2045.Elementary school is the most basic level of education where students begin to learn and understand the relationship of events experienced in their daily life by the material have been learned in school as a character-building process. Through character education, students are expected to have a caring attitude towards the environment, be disciplined in assignments and cooperate with friends (Sugiono et al., 2017).

The 2013 curriculum, which began to be implemented in the school year 2013/2014, in the elementary schools (SD) learning is using an integrated thematic approach for first grades until fourth grade students. In thematic learning, students were required to apply scientific methods such as making observations and experiments according to the material being studied with the aim of students being able to understand the surrounding environment and implement it in everyday life.

Teacher as the manager of learning has the role of facilitating learning to be effective. Educators must help the students to be successful in the future by instilling critical thinking through teaching various academic disciplines (Zivkovic, 2016).Teachers are required to develop learning tools using learning principles: from students being told to students finding out; from the teacher as a single learning source to learn multiple learning resources; from a textual approach to a process as a strengthening of the use of a scientific approach;from partial learning to integrated learning; from learning that emphasizes single answers to learning with answers that are multidimensional in truth; from verbalism learning to applicative skills.

Based on observations made by researcher in fourth grade students of SDN 3 Tubanan, it shown the fact that the learning carried out is direct textual learning and is dominated by the lecture method. The implementation of learning is less effective because of the teacher centered, students tend to be passive, and there is no learning experience that involves the environment and scientific work as a builder of students' scientific literacy skills have not seen yet. During the learning process, the learning more emphasizes on cognitive aspects and involves less affective and psychomotor aspects. The learning only prioritizes mastery of the material by memorizing the concepts was described by the teacher in detail to solve the questions so that the concepts learned do not last long in students' memories. According to Basam et al. (2018) learning using the rote method is one of the causes for the low scientific competence of students.

Observations also shown that the learning resources is used only come from teacher books and student handout whose material is very minimal and not accordance with the student environment, besides that, completeness learning student learning completeness in the evaluation of theme 1 only reaches $41 \%$ or only 11 out of 27 students who achieve minimal completeness is 70 and students have difficulty completing experimental projects in student handout because students are not used to doing scientific work through scientific literacy activities. The opinion tests through interviews and observations for fourth grade students elementary school teachers showed that 10 out of 12 teachers in Kembang District had not developed and used environmentbased learning tools yet. Observations of the learning devices is used to show that Basic Competencies were not suitable, learning models and methods do not involve students' scientific literacy activities, were not interesting and were not developed according to the student's environment. The questions listed in the teaching material have not been able to explore and measure students' abilities because they were not in accordance with the student's environment.

To achieve the learning objectives, the learning tools were developed must accordance by the student's environment to improve scientific literacy skills and solve daily problems. The success of a productive learning process is influenced by good student literacy skills, where is students have a good absorption of the information they get, so they can produce ideas and works (Puspita \& Suciati, 2019). One of the alternatives 
learning usedwas learning by using Environmental-Based Thematic Learning Tools (EBTLT) with a contextual approach which involves students learning to know the environment directly outside the classroom.

Classroom learning outside activities can be said as important as formal education because students can develop their talents and creativity as widely as possible in the nature. (Asiah, 2015). The learning that links learning content to real life can help students to transfer knowledge and problem-solving skills was learned in school to the context of life and help prepare for future careers, citizenship or continuing learning (Smith, 2010).

Scientific literacy activities can be combined with a scientific approach, namely a contextual approach. The contextual approach is a learning concept that links learning material with the environment or the student's real life so that students realize what they were learned is useful for their life later and students will try to achieve it (Sulastri, 2016).

One of the advantages of the contextual model is the learning more meaningful because of constructivist which is requires the students to find and carry out activities related to learning material by themselves. Contextual learning components include constructivism, asking questions, inquiry, learning society, modeling, reflection, and authentic assessment to foster student active learning motivation (Agustiya et al., 2017). By contextual model, students are expected to learn actively in finding their own knowledge through scientific literacy activities from their environment.

Environmentally based contextual models were used in research conducted by Purnamawati et al. (2014), which shows that environmentalbased contextual models have a significant effect on student science learning outcomes and environmentally based contextual models was effectively used in learning. Another study previously conducted by Smith (2010), a student of education at a University in Georgia examined several schools, concluded that contextual models can improve student achievement and perspectives.

Innovation in this research optimizes the cognitive, affective, and psychomotor domains of students by involving the environment as a learning resource which is believed to be able to improve scientific literacy skills, activities, and learning outcomes of students. Based on the background of the problems encountered, the objective of this study was to analyze the effectiveness of environment-based thematic learning tools with a contextual approach in improving students' scientific literacy skills.

\section{METHOD}

This study used a quantitative approach, namely quasi-experimental with 1 control class and 2 experimental classes. The subjects of this study were students of class IVB SDN 3 Tubanan as a control class totaling 25 students, class IVA SDN 3 Tubanan as experimental class 1 totaling 33 students and class IV SDN 1 Tubanan as experiment 2 totaling 27 students. The independent variable was environment-based thematic learning tools with a contextual approach and learning using the lecture method. The dependent variable was science literacy skills and student activities. The treatment instruments in this study were the syllabus, lesson plans, teaching materials, student worksheet, and evaluation questions. Instruments used in this research were observation sheet and test. The observation sheet was used to determine the initial conditions of students and teacher before the study was conducted. The test was used a written test to measure the students' literacy skill in the form of learning outcome data before and after students get, learning using an environment-based contextual learning model. Learning activities in the experimental class were given the same activities, namely using environment-based thematic learning tools with a contextual approach, while the control class was classical learning activities using the lecture method.

The data analysis used effectiveness analysis, which is consisted of individual completeness tests with a standart of minimum completeness mastery learning of 70 and classical completeness $>75 \%$, an increase test ( $\mathrm{N}$-gain), and an independent sample t-test conducted on 
scientific literacy skills and student activities with a significance level $5 \%$.

\section{RESULT AND DISCUSSION}

The learning objective can be well accomplished if it is supported by the appropriate learning tools. A thematic learning device must present to a variety of basic characteristics of thematic learning, which is stimulating students to be active, creating a pleasant learning atmosphere, providing holistic knowledge, and giving immediate experience (Perwitasari et al., 2017). The use of science-based learning tools is crucial to become a stimulus in improving student science competence. Through science-based learning tools, students become accustomed to use their knowledge for the benefit of daily life (Basam et al., 2018). According to Hilmiyati et al. (2018) contextuallearningsubjects to help students understand the sense of learning material by subjects the context of life in the social and cultural environment of society so that it can be used as a course for problems in life.

Environmental-based thematic learning tools with a contextual approach are said to be effective if: 1) students 'scientific literacy skills meet classical completeness, 2) the increase in students' scientific literacy skills was at least in the medium category and 3) the average science literacy skills and student activity scores were higher than control class. The mastery test of science literacy skills in the experimental class 1 and experiment 2 showed the percentage of completeness more than $75 \%$, it was indicated by the zcount value of 3.012 for the experimental class 1 and 3.32 for the experimental class 2 which more than the ztable which was 1.69 .

The increase in the average scientific literacy skills between pretest and posttest by using the $\mathrm{N}$-gain shown an average $\mathrm{N}$-gain value of 0.77 for the experimental class 1 and 0.73 for the experimental class 2 where the $\mathrm{N}$-gain value was the high category. When it was compared with the control class that used the lecture method, the increase in the score between the pretest and posttest had an average $\mathrm{N}$-gain score of only 0.46 which is in the moderate category.

The final test for the effectiveness analysis was posttest mean difference test using the independent sample t-test for science literacy skills scores and student activity scores. The comparison between the control class vs experimental class 1 and the control class vs experimental class 2 . The results of the independent sample t-test in this study were presented in Table 1.

Table 1.Independent Sample T-Test Results for Average Science Literacy Skills

\begin{tabular}{lccl}
\hline Posttest data & $\boldsymbol{t}_{\text {value }}$ & Sig & Category \\
\hline Control vs Experiment 1 & -6.239 & .00 & There was a significant different \\
Control vs Experiment 2 & -5.950 & .00 & There was a significant different \\
\hline
\end{tabular}

Based on the results of the average difference test in Table 1, the significance value of science literacy skills between the control class and the experimental class 1 was 0.000 . Because 0.000 $<0.05$, H0 was rejected, which mean that there was a difference in the average score of students' scientific literacy skills in the control class and experimental class 1 . The average value of the control class was 71.2 and the experimental class average was 85.93 , so it can be concluded that the average scientific literacy skills of the experimental class 1 students was more than the control class.
Meanwhile, the significance value of students' scientific literacy skills between the control class and the experimental class 2 was 0.000 . Because $0.000<0.05$, H0 was rejected, which mean that there was a difference in the average score of students' science literacy skills between the control class and the experimental class 2 . The average value of the control class was 71.2 and the experimental class average was 83.94, so it can be concluded that the average value of the science literacy skills of the experimental class 2 students was more than the control class. The 
results of the independent sample t-test for activity scores have shown in Table 2 .

Table 2. Average Difference Test Score of Student Activity

\begin{tabular}{lcll}
\hline Treatment (class) & $\boldsymbol{t}_{\text {value }}$ & Sig & Category \\
\hline Control vs Experiment 1 & 9.793 & 0.00 & There was significant different \\
Control vs Experiment 2 & 6.015 & 0.00 & There was significant different \\
\hline
\end{tabular}

Based on the results of the difference test in Table 2, it was found that the significance value between the control class and the experimental class 1 and the control class with the experimental class 2 was the same, namely $0.000<0.05$, then $\mathrm{H} 0$ was rejected. This showed that there was a significant difference in the average activity score of the control class students and the experimental class students after being treated or it can be said that there was a significant difference in the average activity score of students who receive lecture learning and students who receive environmental-based thematic learning tools with contextual approach.

The average score of the control class activity was 6.56 and the experimental class 1 was 10.89 , so the experimental class 1 activity score was better than the control class. Meanwhile, the average experimental class 2 was 10.18 , so the activity score of the experimental class 2 was better than the control class. From the comparative test, it was found that the experimental class obtained a higher activity score than the control class. Thus, it can be concluded that the class with environmental-based thematic learning tools with a contextual approach was effective in increasing student learning activities, so it be conclude that implementing PPTBL was effective to increasing students' scientific literacy skills andstudents' learning activities.

This line with the opinion of Hutauruk, Novri, Kristyowati, \& Agung's research (2019). They said that teaching materials based on a contextual approach that utilizes the environment can improve students' scientific literacy skills, which included understanding and caring for the environment. Activities during learning will attract students' attention because of what learned was lifted from the environment so that it related to life and benefits the environment. Learning with an environmental approach mean that students gain understanding and competence by observing and doing in their environment. According to Sulasih et al. (2017), learning with the environment was an effort to create interesting learning and can be an alternative to avoid student boredom.

The aspects attained during learning process in the control class and experiment class are presented in the form of syntactic comparisons of lecture-based and experimental-based thematic learning. As for the syntax learning of control class and experiment classes presented in Table 3.

Table 3. Learning Syntax between Classical Learning and Experimental-Based Thematic Learning

\begin{tabular}{|c|c|c|}
\hline Learning Syntax & Classical Learning/Lecture-Based & Experimental-Based Thematic Learning \\
\hline Observing & Observing the picture & Creating concrete object \\
\hline Asking & $\begin{array}{l}\text { Answering questions about the } \\
\text { picture }\end{array}$ & Students are asking about the concrete object \\
\hline Trying & $\begin{array}{l}\text { Answering questions through } \\
\text { information from the textbook }\end{array}$ & $\begin{array}{l}\text { Conducting direct environmental } \\
\text { observations through learning outside the } \\
\text { classroom }\end{array}$ \\
\hline Thinking & $\begin{array}{l}\text { Discussing } \\
\text { information }\end{array}$ & $\begin{array}{l}\text { Making conclusion based on observation } \\
\text { result }\end{array}$ \\
\hline Communicating & Conveying the discussion result & Presenting the observation result \\
\hline
\end{tabular}


The syntax learning comparison between the lecture-based learning and the environmental based thematic learning is reviewed from the observing, asking, trying, thinking, and communicating. When it is viewed from various aspects, environmental based thematic learning presents observation activities and concrete objects in learning process, unlike lecture-based learning that only presents the picture and information from textbooks. Hosnan's (2014), learning by utilizing the environment as a learning resource was contextual learning, in which the teacher presents the real world into the classroom and guides students to make connections between the knowledge they have and its application in everyday life, but students acquired knowledge indirectly but gradually limited and self-construction as a provision to solve problems in everyday life.For more details, comparision of the average science literacy skills of students are shown in Figure 1.

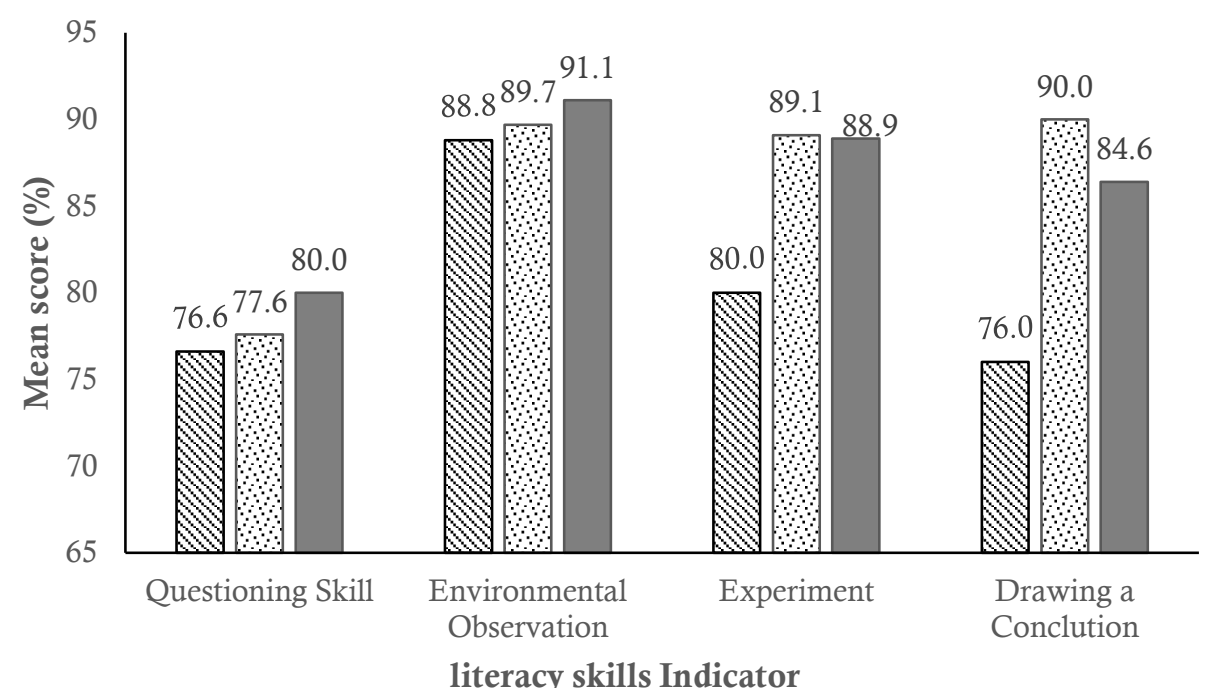

母Control Experiment $1 \square$ Experiment 2

Figure 1. Average science literacy skills Indicator

Four indicators of messuring scientific literacy skill are questioning skill, environmental observation, experiment, and drawing a conclution. Based on the Figure 1 the average score for experiment class 1 and experiment class 2 was higher than control class for each indicator. The most prominent indicators in both the experiment class 1 and experiment class 2 were enviromental observation and experiment. This shown that students' literacy skill increase significantly, due to the activities of experimental observation and experiment during the learning process. So that the children were motivated to learn and aroused curiosity.

Environment-based learning has many advantages, according to Netty et al. (2015) and Ernawulan (2017) that environment-based learning can provide real experiences to students, learning be more concrete, it did not verbalistic because learning with an environmental approach was appropriate with the characteristics and needs of the students. Environmental-based learning made students more willing to take the lessons, be better used to time, did not bored, the lesson be interesting, helped to think more critically, easy to understand the lessons, increased their creativity, and improved the reasons on topics (Irwandi \& Hery, 2019). In addition, lessons became more applicable, so that through environmental media can be apply directly, because students will encounter these objects in daily life. 
With the application of learning based on the environment in the classroom, it be more communicative because of the events and objects around the students' environment usually easier to digest compared to packaged learning media. Based on research article of Cerrvetti et al. (2012), the application of environment-based integrated learning in relation to scientific knowledge, and literacy, it shown that integrated learning greatly affects scientific knowledge, and literacy in elementary schools. The meaning of integrated learning was learning that be combined reading text studies in the classroom with experimental activities in the environment. The results showed that it was not only science literacy skills that had improved, even students' reading, writing, and speaking skills could improve.

The effectiveness of EBTLT with a contextual approach in improving science skills was due to the positive response given by students during the learning process, this showed that students were very interested in the learning model applied. Students' interest can encourage students to be more enthusiastic and interested in learning activities in class so that students can process the information obtained, analyze problems, and ultimately have implications for increasing students' scientific literacy skills.

Students' enthusiasm during the learning process be measured in student activity scores. Based on the results of the study, it was found that the activities of students who received environmental-based learning using EBTLT with a contextual approach higher than students who used the lecture learning method. Contextual learning made students active and creative because they build their own knowledge through involvement in environmental observation, discussion, question, and answer and in creating (Hyun et al., 2020).

The effectiveness of EBTLT learning tools with a contextual approach was supported too by the innovation of learning tools including: the activities can foster character values for students, learning involves the active role of students in obtaining information through direct observation so that it can foster an attitude of curiosity and care for the environment, and through group work can foster an attitude of cooperation and discipline among students.

\section{CONCLUSION}

Based on the results of research and discussion, it can be concluded that students who received EBTLT with a contextual approach in both the experimental class 1 and the experimental class 2 fulfilled the classical completeness more than $75 \%$ of the total students in the class. The increase in science literacy skills of students who received EBTLT with a contextual approach in the experimental class 1 and experiment 2 was higher than that of students in the control class who received the lecture learning method, with the $\mathrm{n}$-gain value of the experimental class being in the high category. There was a significant difference in the average learning outcomes of science literacy skills and the activities of students who used EBTLT with a contextual approach with students who received the lecture method.

\section{REFERENCES}

Agustiya, F., Sunarso, A., \& Haryani, S. (2017). Influence of CTL Model by Using Monopoly Game Media to The Students Motivation and Science Learning Outcomes. Journal of Primary Education. 6(2): 114-119.

Aisah, S. (2015). Penerapan Metode Out Door Activity dalam Pembelajaran IPA untuk Meningkatkan Hasil Belajar Siswa Sekolah Dasar. Jurnal Penelitian Pendidikan Guru Sekolah Dasar. 2(3):1-11.

Basam, F., Rusilowati, A., \& Ridlo, S. (2018). Profil Kompetensi Sains Siswa dalam Pembelajaran Literasi Sains Berpendekatan Inkuiri Saintifik. Pancasakti Science Education Journal.3(1): $1-8$.

Cervetti, G. N., Barber, J., Dorph, R., Pearson, P. D., \& Goldschmidt, P. G. (2012). The 
Impact Of An Integrated Approach To Science And Literacy In Elementary School Classrooms. Journal of Research in Science Teaching. 49(5): 631-658.

Ernawulan. (2017). Membangun Imajinasi dan Kreatifitas Anak Melalui Literasi. Prosiding Seminar Nasional Pendidikan Dasar Volume 2 SPS di UPI Bogor. Bogor, 2015.

Hilmiyati, M,. Anna F. H., \& Sri R. (2018). Contextual Teaching Learning (CTL) Learning Through School Media Environment Utilization To Improve Literacy Of Science And Achievement Test. Edubiologica: Jurnal Penelitian Ilmu dan Pendidikan Biologi. 6(1): 36-43.

Hosnan. (2014). Pendekatan Saintifik dan Kontekstual dalam Pembelajaran Abad 21. Bogor: Ghalia Indonesia.

Hutauruk, Elisabeth, N., \& Situmeang, R. W. (2019). Analisis Sikap Toleransi Siswa dalam Pembelajaran Ipa Terpadu. Magistra: Jurnal Keguruan dan Ilmu Pendidikan. 6(1): 110-118.

Hyun, C. C., Wijayanti, L. M., Asbari, M., Purwanto, A., Santoso, P. B., Igak, W., Bernarto, I., \& Pramono, R. (2020). Implementation of contextual teaching and learning (CTL) to improve the concept and practice of love for faithlearning integration. International Journal of Control and Automation. 13(1): 365-383.

Irwandi \& Hery F. (2019). Pemanfaatan Lingkungan sebagai Sumber Belajar untuk Meningkatkan Minat dan Hasil Belajar Siswa SMA di Kawasan Pesisir, Kalimantan Selatan. Jurnal Biologi-Inovasi Pendidikan. 1(2): 66-73.

Kristyowati R. \& Agung P. (2019). Pembelajaran Literasi Sains Melalui Pemanfaatan Lingkungan. Jurnal Pendidikan dan Kebudayaan. 9(2):183-191.

Perwitasari, S., Wahjoedi, \& Akbar, S. (2017). Bahan Ajar Tematik Berbasis Kontekstual untuk Siswa Sekolah Dasar. Jurnal Pendidikan Humaniora. 3(3): 278-285.
Purnamawati, K. A., Suardika, R., \& Manuaba, S. (2014). Pengaruh Penerapan Model Pembelajaran Kontekstual Berbasis Lingkungan terhadap Hasil Belajar IPA Siswa Kelas V SD di Gugus I Gusti Ngurah Rai Denpasar Selatan. Jurnal Mimbar PGSD Universitas Pendidikan Ganesha, 2(1): 1-10.

Puspita, A. M. I. \& Suciati P. (2019). Pengaruh Bahan Ajar Berbasis Literasi dengan Pendekatan Kontekstual terhadap Hasil Belajar Siswa Sekolah Dasar. Journal of Islamic Primary Education. 2(1): 1-7.

Sitanggang N. D. H. \& Niken H. (2015). Peningkatan Motivasi Belajar Tentang Tumbuhan Melalui Pemanfaatan Lingkungan Sebagai Sumber Belajar. Jurnal Ilmiah Kependidikan. 2(3): 207-222.

Smith, B. P. (2010). Instructional Strategies in Family and Consumer Sciences: Implementing the Contextual Teaching and Learning Pedagogical Model. Journal of Family \& Consumer Sciences Education Education. 28(1): 23-38.

Sugiyono, T. S., Sri S., \& Ani R. (2017). Pengembangan Perangkat Pembelajaran IPA Bervisi Sets dengan Metode Outdoor Learning untuk Menanamkan Nilai Karakter Bangsa Abstrak. Journal of Primary Education. 6(1):8-20.

Sulasih, B., Syamwil R., \& Wilonoyudho S. (2017). Pengembangan Model Pembelajaran Outdoor Study Berbasis Keunggulan Lokal pada Siswa Sekolah Menengah Kejuruan. Journal of Vocational and Career Education. 2(1): 79-85.

Sulastri, A. (2016). Penerapan Pendekatan Kontekstual dalam Pembelajaran Matematika untuk Meningkatkan Pemahaman Konsep Matematis Siswa Sekolah Dasar. Jurnal Pendidikan Guru Sekolah Dasar. 1(1): 156-170.

Zivkovic, S. (2016). The ESP TechnologySupported Learning Environment. European Journal of Social Sciences Education and Research. 3(1): 154-161. 